Open Access

\title{
Conceptual mapping of shared value creation by the private commercial banks in Bangladesh
}

\author{
Md. Rabiul Islam ${ }^{1 *}$ and Syed Zabid Hossain ${ }^{2}$
}

\author{
* Correspondence: rabiul@hum.ruet. \\ ac.bd; rabi54mba@yahoo.com \\ ${ }^{1}$ Department of Humanities, \\ Rajshahi University of Engineering \& \\ Technology (RUET), Rajshahi 6204, \\ Bangladesh \\ Full list of author information is \\ available at the end of the article
}

\begin{abstract}
Creating shared value is the opportunity driven approach of business entities to benefit the less addressed segment of the society through their core products and services. For bank financial institutions, the opportunity driven approach signifies that banking corporations ought to identify bankable needs that are less addressed or unaddressed and invest on purpose to benefit both society and business. The study strives to develop a conceptual model of how Private Commercial Banks (PCBs) in Bangladesh are creating shared value (a popular concept developed by ([Porter ME, Kramer MR], [The big idea: creating shared value; how to reinvent capitalism-and unleash a wave of innovation and growth], [2011])) through reviewing the products and services of PCBs in light of available literature in the field of strategic corporate social responsibility and creating shared value. The model has identified core products and services that are creating shared value for both the bank and the society concurrently. It has also identified factors that are limiting shared value creation capacity of PCBs. Thus, the model will assist the money market policy planners especially bankers to identify the products, services, markets, and value chain that could augment capacity of creating shared value and remove the roadblocks for creating upscale shared value in the developing country context.
\end{abstract}

Keywords: Creating shared value, Shared value, Strategic banking, Banking on shared value

\section{Introduction}

Balanced economic growth and prosperity of a developing country like Bangladesh basically depends on reducing the gap between rich and poor as well as between rural and urban people through satisfying their unmet or less focused social needs. The mentionable social needs of the country include but are not limited to food security, greater financial security, better health, better housing, quality education, improved nutrition, support for disable and aged people, support for disaster prone communities, support for agriculture and Small and Medium Scale Enterprises (SMEs), support for the women entrepreneurs, access to formal banking, and environmental protection (Islam and Hossain, 2018a). Perhaps, these are "the highest unmet needs in the global economy and corporate entities have a leading role in fulfilling these needs" (Porter and Kramer, 2011).

(c) The Author(s). 2019 Open Access This article is distributed under the terms of the Creative Commons Attribution 4.0 International License (http://creativecommons.org/licenses/by/4.0/), which permits unrestricted use, distribution, and reproduction in any medium, provided you give appropriate credit to the original author(s) and the source, provide a link to the Creative Commons license, and indicate if changes were made. 
Banking corporations being the center of all economic functions have a principal role in formulating appropriate agriculture, SME, environmental risk reduction, women entrepreneurship development, and rural micro-credit policy to satisfy those unmet needs and challenges. It is also necessary to bring the unbanked rural people into the formal banking network and services to accelerate their socio-economic development. The sound business mix of banking industries should be developed in such a way that, at the one hand, could ensure economic success of banks and best serve the society on the other (Islam, 2017).

Unfortunately, majority of the banking corporations is less focused or not at all focused on creating shared value (value for both the business and society simultaneously). Most of the banks and non-bank financial institutions are addressing social issues through so called philanthropy, which contribute to mitigate some sort of social problems at the expense of the stockholders through low dividend and tax exemption. Furthermore, they are maximizing short term profit through providing loans to inessential areas and locating branches mostly in the urban areas with high profit prospect thus leaving many rural people with small saving unbanked.

However, some PCBs are to some extent creating shared value (i.e., looking for societal interests for their self interest) by taking it as the core of their banking business. They are creating Shared Value through promoting innovative and entrepreneurial banking products such as financing for SMEs, agricultural, women entrepreneurship development, environment friendly business as well as promoting farmers banking and school banking. Besides, in order to bring the unbanked or under-banked rural mass into the banking network and services, some PCBs are proactively engaging into the mobile financial services that offer instant money transfer from one corner of Bangladesh to another along with other banking services using cell phone. Some others are intensifying their rural branches to cater to the banking needs of the SMEs, agriculture and unbanked or under-banked rural people. Majority of the PCBs are engaging in such endeavors merely to comply with the directives relating to inclusive and sustainable development set by the regulatory body. However, some are taking these initiatives as a part of their core banking choice in order to increase competitive viability. The study thus aims to develop a conceptual model of creating shared value by private commercial banks in Bangladesh in light of the Creating Shared Value (CSV) concept developed by Porter and Kramer.

\section{Literature review}

Concept of CSR

Although the concept of corporate social responsibility (CSR) has been advocated for decades (Caroll, 1999; Jenkins, 2005) and is commonly deployed by corporations globally, agreement on how CSR should be defined and implemented remains a debatable issue in academic circles, business and society (Hemingway, 2002; Matten and Moon, 2008; Smith, 2011). CSR is the obligations of businessmen to pursue those policies, to make those decisions, or to follow those actions that are desirable in terms of the objectives and values of particular society 
(Bowen, 1953, p.44). Similarly, CSR is the businessmen's decisions and actions that go beyond the firm's direct economic and technical interest (Davis, 1960, p.70). It is not only economic and legal obligations of corporations but also certain responsibilities to society which extend beyond these obligations (McGuire, 1963; Davis and Blomstrom, 1966). Fitch (1976) observed CSR as the serious attempt of corporation to solve social problems caused wholly or in part by it. Carroll (1979) blended the aforementioned definitions of CSR into a four-part definition: economic, legal, ethical and discretionary expectations that society has on organizations at a given point in time. Later on, Carroll (1991) revisited his four-part definition adding ethical and philanthropic functions.

Despite the above mentioned historical definitions of CSR, the concept is still changing from country to country and organization to organization. Matten and Moon (2008) conceptualized CSR in a European context and differentiated between explicit and implicit CSR. Explicitly CSR referred to as voluntary and self driven policies and strategies of corporations to address issues perceived as being part of their social responsibility. Implicitly CSR referred to the values, norms and rules which compel corporations to address issues stakeholders consider a proper obligation upon corporate actors. The World Business Council for Sustainable Development (WBCSD, 1998) characterizes CSR as an 'enduring word of honor by business to act morally and contribute to economic growth while improving the quality of life of the workforce and their families as well as of the local community and society at large'.

Thus, the definitions of CSR vary significantly as different authors and organizations defined it in different ways. From the aforementioned definitions of CSR, it can be characterized as voluntary activities of business firm, giving back to society, ethical practices, corporate philanthropy, isolated from core business activities and company profitability, and it is done at the expense of the shareholder's money for which they receive no direct return.

\section{Arguments against CSR}

CSR provides corporations with strategic ideas to fulfill stakeholders' needs and to comply with social responsibility (Clarkson, 1995). Moreover, it allows corporations to limit their scope to a selection of problems faced by societies (Clarkson, 1995). However, this kind of social responsibility or philanthropy is done due to external pressure (Bendell, 2004; Broomhill, 2007; Porter and Kramer 2011) and thus there is an incredible debate about its efficacy. CSR efforts are sometimes criticized as nothing more than 'window dressing, 'blue washing,' 'green washing' or a 'giant public relations campaign' (Waddock, 2008). Scholars have agreed that CSR efforts are good for society but they varied their opinion regarding the direct benefits of those efforts to the shareholders of the firm (Mcwilliams et al., 2006; Hart and Milisten, 2003; Porter and Kramer, 2006, 2011). Academic studies on this subject have focused on investigating the interrelationship between CSR and corporate financial performance. Some researchers have found that CSR engagement of firms improves financial performance (Bruke and Logsdon, 1996; Orlitzky et al., 2003; Cochran and Wood, 1984). Others have found that there is no correlation between CSR 
engagement of firms and improvement of financial performance (Griffin and Mahon, 1997; Mcwilliams and Siegel, 2000; Margolis and Walsh, 2001).

\section{Transforming focus from CSR to CSV}

Although researches show equivocal relationships, there is however no way to avoid CSR because of the interrelationship between business and society. Business enterprises depend on society for all sorts of resources, securities, recognitions, and customers for the products or services they offer. Conversely, society depends on business for products or services, employment and the like. Moreover, various business actions have negative social and environmental impacts that should be addressed by the business itself. Vogel (1992), in Campbell, 2007, p.947) observed that deceiving customers, swindling investors, exploiting and even abusing employees, putting consumers at risk, poisoning the environment, cheating the government etc. by corporations are not uncommon. Still, some corporate entities do opposite of those irresponsible behaviors by giving to charities, supporting community activities, treating their workers and customers decently, obeying laws, and maintaining standards of honesty and integrity (Campbell, 2007, p.947).

The voluntary giving or philanthropy such as charities, supporting community activities etc. to society at the expense of corporate stockholders is not sufficient to meet the huge unmet needs of large number of people of a developing country. Now the question arises, how corporations can balance between business and social interests. Porter and Kramer (2011) have argued that both the social and business interests can be harmonized through 'creating shared value' which involves "creating economic value in a way that also creates value for society by addressing its needs and challenges". In their prior research, the authors mentioned the fact that the existing approaches to CSR are disconnected from core business strategies and therefore they are hindering corporations from capitalizing greatest opportunities to benefit society (Porter and Kramer 2006). The authors suggested corporations to analyze their prospects for social responsibility through core business choices in order to make it a source of opportunity, innovation, and competitive advantage (Porter and Kramer 2006).

\section{CSR vs CSV}

Both CSR and CSV approach advocate corporations to address social needs, to comply with laws and ethical standards, and to reduce noxiousness of corporate activities. Nonetheless, there are some significant differences between the two approaches.

Unlike CSR, which assume businesses to consider social responsibility as supplementary, the shared value approach assumes that social responsibility is the center of every business performance. Shared value is not about personal values, nor about "sharing" the value already created by firms as is assumed by CSR. Instead, shared value is about expanding the total pool of economic and social value (Porter and Kramer, 2011). That means shared value is created when business undertake various unmet or less addressed social needs and challenges as business opportunity. Hence, earning fair profit from social purpose is justified. This concept takes into account philanthropy only when it creates social as well as business value. 
CSR is done voluntarily and it is not directly related to profitability, productivity, and competitive advantage, whereas CSV is integrated with core products and services of corporations therefore, directly linked to profitability, productivity, and competitive advantage.

CSR is done in response to external pressures (Epstein, 1989; Wood, 1991; Porter and Kramer 2011) and corporate preferences to get tax exemptions but CSV is internally generated and company specific (Porter and Kramer 2011, Lapina et al., 2012).

CSR approach denotes value as 'doing good' for someone or something from the business profit but the CSV approach "looks at surrounding environment and society as part of the business model; hence doing good for the society is a prerequisite for doing well in business" (Lapina et al., 2012, p.1607).

\section{Framework for analyzing CSV}

The CSV argues that companies can create shared value in three distinct ways: reconceiving products and markets, redefining value chain to improve productivity, and enabling supportive local clusters (Porter and Kramer, 2011). These three ways are clarified below as their characteristics are imperative for data analysis.

\section{Way 1: Reconceiving products and markets}

Porter and Kramer (2011) defined it as satisfying unmet or less addressed needs of the disadvantaged communities. That means if poor and disadvantaged section of the society is benefited from corporate products and services, shared value is created. PCBs in a developing country can satisfy unmet banking needs of large number of unbanked people through investing in innovating products such as SME (including firms of women entrepreneurs), agriculture (including rural microfinance), mobile financial service and environment friendly banking. PCBs can also involve in educating stakeholders, building trust on banking activities, showing concern and caring for employees in the workplace, creating direct and indirect employment opportunities, and helping the distressed and vulnerable people. Hence, business value can be measured through improved profitability, productivity, market share, quality, goodwill, brand image, and reduced operating costs and resources use. Whereas, social value can be measured through improved job creation, banking access, beneficiary income, regulatory compliance, government income, customer and employee learning, responsible \& ethical practices, less environmental footprint and many more.

\section{Way 2: Redefining value chain to improve productivity}

CSV argues that as social problems create economic costs in the firm's value chain, company must look for factors that might affect its energy and resources use, logistics, distribution, health and safety, working conditions, equal treatment in the workplace and employee productivity (Porter and Kramer, 2011). PCBs in a developing country can improve productivity through redefining their value chain activities in terms of online banking, ATMs, CDMs, easy money transfer, e-commerce, cash management and call center services. PCBs can also improve productivity through in-house environment friendly practices. Some of the actions include: 
using electronic form for internal memos, notes, records, communicating with customer through e-mails, SMS or ATM display instead of letter communication; using video conferencing system to communicate with bank officials; and using solar energy as a source of power. These practices will not only save corporate money through reducing paper, energy and transport use but also ecological footprint. Moreover, when customers find quality service conveniently, reliably and at low cost, shared value is created.

\section{Way 3: Enabling supportive local clusters}

Porter and Kramer (2011) defined cluster as "geographic concentration of firms, related businesses, suppliers, service providers, and logistical infrastructure in a particular field". The authors emphasized that clusters are prominent in all successful and growing regional economies and play a crucial role in achieving productivity, innovation, and competitiveness. PCBs can create shared value through cluster based financing while addressing gaps in the framework conditions surrounding the cluster.

\section{Measuring CSV}

Porter et al. (2012) proposed a four-step shared value measurement process. First, identifying the social issues to target; second, making the business case; third, tracking progress; and forth measuring results and use experiences to create new value. Several other authors contributed to the shared value measurement process. Dembek et al. (2016) suggested looking for three key areas of shared value concept, which have created the concept, its outcomes, and the beneficiaries of the outcomes. Maltz et al. (2011) developed a nine-step method on resource and externalities-based view in society to compare multiple shared value initiatives on their costs and benefits. Pfitzer et al. (2013) proposed a three-step assessmentfirstly, estimate business and social value linking change in social condition to profits; secondly, establish immediate measures and track progress to validate the anticipated link; and finally, assess the shared value produced by measuring the ultimate social and business benefits. Spitzeck et al. (2013) proposed a series of organizational and societal indicators that include financial (profitability, growth, competitive capabilities, and strategic repositioning) and intangible value (reputation, risk reduction, access to government, and long-term legacy) as organizational indicators as well as enhanced positive impact and reduced negative impacts as social indicators.

\section{Definition of key terms}

Bank stakeholders: A stakeholder is "an individual or group who can affect, or is affected by, the achievement of the organization's objectives" (Freeman, 1984, p.46). In this study, stakeholders are individuals or group benefited by the policies and practices of banks. They include employees, customers, stockholders, government, rural community, competitors, and regulators.

Regulators: The authorities that regulate policies and practices of banks and includes the following: Bangladesh Bank, Bangladesh Securities and Exchange Commission 
(BSEC), Dhaka Stock Exchange (DSE), Chittagong Stock Exchange (CSE), and Central Depository Bangladesh Limited (CDBL).

Productivity: Productivity is the efficient use of resources- employees, loans and advances, various funds, materials, energy etc.

SME: The study adopted the definition of SMEs given by Bangladesh Bank (shown in Table 9 in Appendix).

Social problems: Social problems refer to a gap between society's expectations of social conditions and present social realities.

Social benefits: Social benefits represent financial as well as nonfinancial gain to unfocused or less focused segment of the society.

\section{Research design and methodology Population and sample}

The study was concentrated on private commercial banks in Bangladesh. Shared value performance of banks depends on huge investment, which is not possible without raising sufficient equity from the capital market. Therefore, the study population was all the 30 listed commercial banks in DSE and CSE. The study purposively selected $50 \%$ of the listed PCBs (Table 8 in Appendix).

\section{Reason of purposive sampling}

The sample was selected purposively considering (Ahmad et al., 2003) the number of shared value product offerings and the volume of transactions in those products; (Bendell, 2004) the extent of social orientations; (Bissoon, 2018) the integration of social activism in their mission, vision and core objectives; and (Bowen, 1953) the disclosures of information in their annual reports. The study did not consider other banks, non-bank financial institutions and manufacturing companies because their nature of business varies significantly and as such it is not possible to analyze their shared value creation in a single framework.

\section{Data collection}

The study is predominantly qualitative in nature. However, quantitative information has also been used to supplement qualitative data. Both kinds of data have been collected exclusively from secondary sources. The study has used content analysis as a technique for evaluating innovative banking products that are creating shared value and to recognize the challenges for creating shared value. The content analysis, a technique for gathering and analyzing the meaning, ideas, themes, or message of text (Neuman and Kreuger, 2003), has been made on the basis of corporate annual reports (Bissoon, 2018; Rizk et al., 2008; De Villiers and Van Staden, 2006; Ahmad et al., 2003; Deegan and Gordon, 1996). Although corporate information can be disseminated in a number of ways such as corporate newsletters, research reports, websites and media, the researchers were motivated by the fact that the annual report is a statutory document and can be considered more reliable than other means of disclosure (Neu et al. 1998; Gray et al., 1995). The annual reports during the period 2011-2015 were downloaded from the websites of sample companies. Sample PCBs maintain company websites and provide information regarding shared value products via downloadable PDF 
format documents of their annual reports. Company annual reports during the study period have been used to demonstrate whether the CSV performance of the selected PCBs was incessant over the period.

The study has also critically reviewed accessible literature in the study area to appraise the contributions of prior researchers and to pinpoint the research gap. Certain parameters have been used so as to include the most relevant and quality literature in the field. Journal articles have been searched using the ISI web of knowledge database and Google Scholar database, using the key words: creating shared value, corporate social responsibility, bottom of the pyramid theory, stakeholder theory, strategic CSR, and banking on shared value. In addition to journal articles, relevant research reports, and published and unpublished dissertations have also been critically reviewed.

\section{Conceptual mapping of shared value creation by the PCBs in Bangladesh}

The selected PCBs offer a bundle of products and services to cater to the diverse needs of their customers. Their main products are offered through several functional divisions such as consumer/retail banking, corporate banking, SME banking, off-shore banking, treasury banking, brokerage operations, and Islamic banking. Their core business and banking includes customers deposits, short term credit to large corporations, finance to SMEs (including firms of women entrepreneurs) and agriculture (rural microfinance), organize syndicated deals and structured finance, conduct retail business, import and export financing, project financing, hire purchase financing, issue local and international credit cards, deliver Islamic banking services based on Shariah principles, channel remittance from abroad and provide off-shore banking services. Banking services have been extended to vast areas such as Automated Teller Machine (ATM) service, remittance service, locker service, online banking, mobile banking, and school banking. Hence, it is worth mentioning that many products and services are creating value either for business or for society or both, but all products and services are not creating Shared Value.

Figure 1 in Appendix presents the conceptual mapping of shared value creation for the PCBs in Bangladesh in line with Porter and Kramer's shared value model. The figure reveals that PCBs are creating shared value (long term business value and social \& environmental value simultaneously) through their core banking operations (innovative products and services) that are meeting the banking needs of the bottom of the pyramid. The selected PCBs are to some extent focusing on the following innovative products to meet the banking needs of the bottom of the pyramid are categorized as SME (including firms of women entrepreneurs), agriculture (including rural micro credit), mobile financial services, environment friendly banking, and school banking. The PCBs are also focusing on time, cost, convenience and easiness of customers for those innovative products (Islam and Hossain, 2018b). To do so, banks have also been broadly innovating their services such as ATMs, Cash Deposit Machines (CDMs), fast track, agent banking, online banking, SMS, call centers, corporate cash management, locker, remittance, advisory, brokerage, E-Commerce, contract farming, cluster based financing etc. The core banking operations of PCBs are creating concurrent value for both the business and society. The core banking operations are creating business value of PCBs in terms of improved profitability, productivity, market share and corporate reputation. 
Simultaneously, the core banking operations are also creating social value in terms of (i) enhanced job creation in the banks and self employment opportunities in rural areas, (Bendell, 2004) access to banking for the unbanked, (Bissoon, 2018) service and comfort for customers, (Bowen, 1953) regional development, (Broomhill, 2007) regulatory compliance, (Burke \& Logsdon, 1996) government income, (Campbell, 2007) employee and customer learning, and (Carroll, 1979) reduced environment footprint among other.

Quantitative analysis in Table 2 in Appendix reveals that in absolute terms, the total SME exposure of all PCBs had an increasing trend over the period of review; but in relative terms with total general investment (loans), it had a decreasing trend in majority (53\%) of the sample banks except in IBBL, DBL, EBL, JBL, MBL, SBL and NBL. In relative terms, SME investment had increased by $18.5 \%$ in JBL followed by $8.24 \%$ in IBBL, 6.99\% in SBL, 4.95\% in DBL, 2.21\% in EBL and 1.21\% in NBL. In relative terms total SME exposure had decreased by $18.83 \%$ in UBL followed by $16.98 \%$ in DBBL, 9.24\% in ABBL and 6.25\% in BBL. Thus it can be concluded that the investment in SME (most notable shared value product) to general investment decreased in most of the cases though in absolute terms the amount of SME exposure increased in all the cases. Thus, PCBs should consider the relative investment in SME with total general investment rather than absolute investment in this particular product.

It is observed in Table 3 in Appendix that both in absolute and relative terms, the total agricultural disbursement had a fluctuating but decreasing trend in all the cases except an insignificant increasing trend in EXBL, EBL, DBL, SIBL, JBL, MBL and SBL. The rate of decline was more pronounced in DBBL than others banks as in absolute term it decreased by 0.21 times and in relative terms with general investment (loans) it decreased by $12.55 \%$ over the period. More revealing is that the PCBs had very insignificant amount of investment in agricultural sector with gradual decreasing trend in most of the cases though the rural economy of Bangladesh is highly dependent on agriculture. To disburse rural micro credit, most of the PCBs are depending on Micro Finance Institutes (MFIs) or Non-Government Organizations (NGOs) linkage due to inadequate rural branches which slightly pushing extra cost to farmers.

Table 4 in Appendix corroborates that $66.67 \%$ of the selected banks reported that they had green (environment friendly) investment. In IBBL, EBL, UBL and SBL, green investment had an increasing trend in both absolute terms $(2.89,1.35,33.26$ and 4077.33 times respectively) and in relative terms with total general investment $7.47 \%$, $0.0004 \%, 0.0043 \%$ and $0.104 \%$ respectively over the period of review. But in EXBL, JBL, $\mathrm{MBL}$ and IFICBL, the growth rates were negative in relative terms despite having an increasing trend in absolute terms. Hence, it is worthwhile to note that the entire sample PCBs arranged green training session for their employees. Regarding in-house green practices, all sample banks had reported that they are gradually improving their internal green practices including using online facilities for internal memos, notes and records; communicating with customer through e-mails, SMS or ATM display instead of letter; using video conferencing system to communicate with bank officials; and using solar energy as a source of power.

Table 5 in Appendix reveals BBL, DBBL, UCBL had mobile banking services and in all the three cases total number of mobile bank accounts and total 
number of agent points had increased manifold over the period. In BBL, total no of mobile bank account increased to 10.37 times and total no of agent points increased to 23.78 times, in DBBL 105.55 times and 107.67 times and in UCBL (newly introduced mobile banking services) 2.26 times and 1.04 times respectively.

Similarly, Table 7 in Appendix testimonies that EPS had an increasing trend in all PCBs over the period. Concomitantly, Table 8 in Appendix discloses that the contribution of PCBs to National Exchequer had increased over the period.

The overall findings of the study suggest that the PCBs are creating shared value mostly through reconceiving their products and services and redefining their value chain to boost productivity. They are also enabling local clusters emphasizing cluster based financing to a limited extent (20\% PCBs had reported the same). In other words, PCBs in a developing country like Bangladesh are creating shared value in line with Porter and Kramer's shared value concept.

Of course, all PCBs are not equally emphasizing all shared value products. It is evident that in terms of amount of investment in SMEs including firms of women entrepreneurs, agriculture, and green (environment friendly) financing, IBBL comes first (Tables 2, 3, and 4 in Appendix).

It is also evident that mobile financial services were expanded quickly by bKash of BBL, followed by Rocket of DBBL, while mobile financial services from other PCBs were expanded very slowly (Table 5 in Appendix). In terms of ATMs, fast track with CDMs and agent banking expansion, DBBL comes first (Table 6 in Appendix). Table 6 in Appendix demonstrates that DBBL had ATM units and Fast tracks services and in both the cases growth rates over the period were 1.85 times and 3.42 times respectively. A point is to note that other banks are sharing DBBL's network although their ATM network are growing steadily. In terms of customers' served, employee recruitment and customer self employment training, IBBL is ahead of others (Tables 7 and 8 in Appendix). Regardless of the differences in the shared value performance, it can be concluded that the PCBs in Bangladesh are considering social needs as business opportunities to create shared value particularly for stakeholders.

Figure 1 in Appendix has also identified several factors that could modify the shared value creation capacity of PCBs. In other words, the PCBs in Bangladesh need to address the following issues to create up-scale shared value:

1. Involving in ethical practices:

- safe custody

- value based banking

- online transactions

- safe e-commerce

- good governance

2. Identifying and overcoming challenges: 
- Internal challenges:

- High operating costs due to more manpower needed to serve the shared value market

- Low return expectation

- Inadequate delivery channel in rural areas

- Insufficient fund to invest in low profitable areas

- Short term profit mentality

- Lack of employee training and education to serve the bottom of the pyramid

- External challenges:

- Enormous gaps between lending rate and deposit rate

- Low customer demand of some of the shared value products and services

- Intense competition within the industry and from a large number of non-bank financial institutions, mobile phone operators and NGOs

- Lack of collateral

- Lack of banking education of rural customers

- Reducing non-performing loans (NPLs)

- Local political pressures

- Rapid changes in government regulatory policy

- Deteriorating law and order situations

3. Managing stakeholders' interests

4. Clarifying motives of operations

- goodwill

- brand image

- social acceptance and

- profit

The study presumes that the more the PCBs will practice ethical standards such as value based baking, safe custody, online transactions etc., the more they could create shared value. Managing stakeholders' interest in the best possible ways as well as enhancing goodwill, brand image, profit, and social acceptance of business could also help create shared value. However, internal and external challenges could negatively influence shared value efforts of PCBs to scale up faster. Hence, mitigating those challenges for creating and cultivating upscale shared value is extremely desirable.

\section{Conclusion}

In order to get competitive advantage from creating shared value, PCBs have to be innovative in product development to address the unmet needs and challenges of broad range of customers as well as to be efficient in banking operations through supply chain management and local cluster development. The success of shared value strategy relies on the compliance of codes of conduct set by the regulators, ethical standards, leadership commitment to social issues, and positive attitudes, cooperation and commitment of the working force. The effectiveness of this 
strategy also relies on setting shared value standard or social goal, measuring actual performance or outcome, and taking corrective actions if any deviation from the standard is observed. To do so, PCBs need to keep record for social and business outcomes and make progress every year to reach the shared value at scale. In addition, PCBs need to cope with internal as well as external challenges that hinder the long-term success of the strategy. Furthermore, attitude and awareness of stakeholders influence the social and business outcomes. Therefore, PCBs should properly manage their stakeholders' interests.

\section{Limitations of the study and areas for future research}

The study suffers from some limitations. Firstly, the findings are based on the published secondary data, which may not represent the actual motives of the board of directors, stockholders and managers since strong motivation is essential for social endeavors as the core to create upscale shared value. Secondly, it is also essential to comprehend the perceptions of bank stakeholders' regarding the effectiveness of existing shared value products and services. Finally, the current study is an account of PCBs only. Government owned commercial banks, non bank financial institutions and branches of foreign commercial banks could be included in this study. Future researchers are expected to overcome such limitations through conducting comprehensive interviews with different stakeholders of bank and nonbank financial institutions to validate the findings.

\section{Appendix}

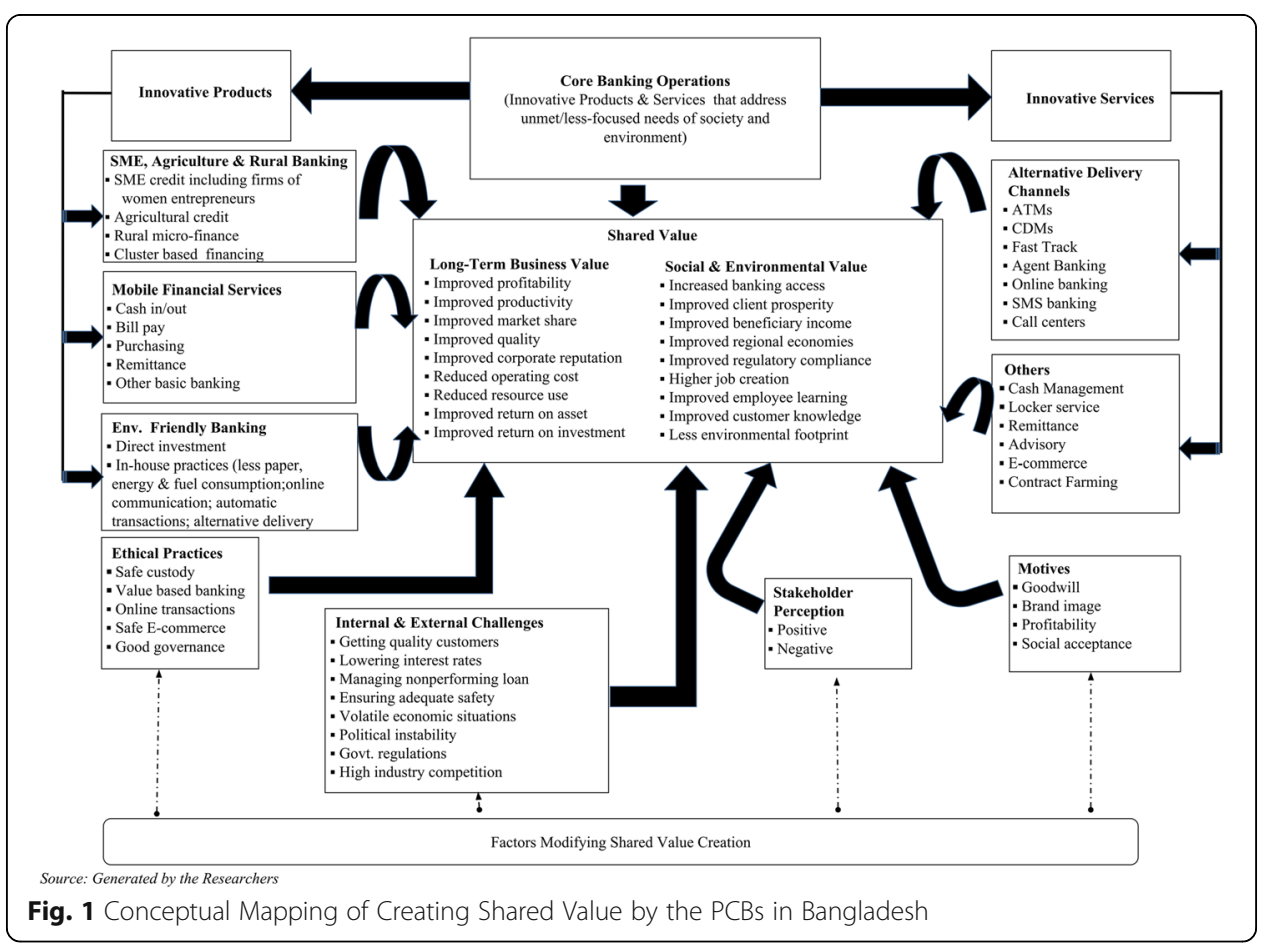


Table 1 List of Sample PCBs Enlisted in DSE \& CSE

\begin{tabular}{lll}
\hline SI. No. & Name of PCB & Founding Year \\
\hline 1. & Arab Bangladesh Bank Limited & 1982 \\
2. & IFIC Bank Limited & 1983 \\
3. & Uttara Bank Limited & 1983 \\
4. & National Bank Limited & 1983 \\
5. & Islami Bank Bangladesh Limited & 1983 \\
6. & United Commercial Bank Limited & 1983 \\
7. & Eastern Bank Limited & 1992 \\
8. & Dhaka Bank Limited & 1995 \\
9. & Southeast Bank Limited & 1995 \\
10. & Dutch-Bangla Bank Limited & 1996 \\
11. & EXIM Bank Limited & 1999 \\
12. & Mercantile Bank Limited & 1999 \\
13. & BRAC Bank Limited & 2001 \\
14. & Jamuna Bank Limited & 2001 \\
15. & Shahjalal Islami Bank Limited & 2001
\end{tabular}

Source: Compiled by researchers from official Website of DSE 
Table 2 SME Sector Investment of Selected PCBs

\begin{tabular}{|c|c|c|c|c|c|c|c|}
\hline \multirow{2}{*}{$\begin{array}{l}\text { Name } \\
\text { of PCB }\end{array}$} & \multirow[t]{2}{*}{ Particular } & \multicolumn{5}{|c|}{ Year-Wise Data (Amount in Million BDT) } & \multirow{2}{*}{$\begin{array}{l}\text { Growth } \\
\text { Over } \\
\text { the } \\
\text { Period } \\
\text { (Times) }\end{array}$} \\
\hline & & 2011 & 2012 & 2013 & 2014 & 2015 & \\
\hline \multirow[t]{3}{*}{ IBBL } & SME loan & 108,670 & 149,214 & 173,660 & 201,127 & 232,080 & 2.14 \\
\hline & Total loans & 305,841 & 372,921 & 403,195 & 463,475 & 530,194 & 1.73 \\
\hline & SME loan to total loans (\%) & 35.53 & 40.01 & 43.07 & 43.40 & 43.77 & $8.24 \%$ \\
\hline \multirow[t]{3}{*}{ UCBL } & SME loan & N/A & $57,545.60$ & $70,246.60$ & $87,670.00$ & $80,598.30$ & 1.40 \\
\hline & Total loans & N/A & $136,071.65$ & $148,664.86$ & $174,146.10$ & $197,413.64$ & 1.45 \\
\hline & SME Ioan to total loans (\%) & N/A & 42.29 & 47.25 & 50.34 & 40.82 & $-1.47 \%$ \\
\hline \multirow[t]{3}{*}{ DBBL } & SME loan & $30,868.00$ & $25,137.00$ & $32,284.00$ & $28,225.20$ & $33,138.20$ & 1.07 \\
\hline & Total loans & $79,660.70$ & $91,648.90$ & $106,422.80$ & $124,423.00$ & $152,270.00$ & 1.91 \\
\hline & SME loan to total loans (\%) & 38.74 & 27.42 & 30.33 & 22.68 & 21.76 & $-16.98 \%$ \\
\hline \multirow[t]{3}{*}{ DBL } & SME loan & 4129 & 4770 & 8703 & 10,725 & 12,227 & 2.96 \\
\hline & Total loans & 75,983 & 90,140 & 99,596 & 103,131 & 117,840 & 1.55 \\
\hline & SME loan to total loans (\%) & 5.43 & 5.29 & 8.74 & 10.39 & 10.38 & $4.95 \%$ \\
\hline \multirow[t]{3}{*}{ EXBL } & SME loan & $43,093.90$ & $46,853.60$ & $64,717.70$ & $84,825.90$ & $83,962.90$ & 1.95 \\
\hline & Total loans & $99,699.63$ & $118,219.99$ & $143,847.38$ & $177,936.84$ & $196,311.42$ & 1.97 \\
\hline & SME loan to total loans (\%) & 43.22 & 39.63 & 44.99 & 47.67 & 42.77 & $-0.45 \%$ \\
\hline \multirow[t]{3}{*}{$\mathrm{BBL}$} & SME Ioan & 32,140 & 33,399 & 33,676 & 38,142 & 42,963 & 1.34 \\
\hline & Total loans & 90,822 & 103,624 & 117,111 & 121,941 & 147,434 & 1.62 \\
\hline & SME loan to total loans (\%) & 35.39 & 32.23 & 28.76 & 31.28 & 29.14 & $-6.25 \%$ \\
\hline \multirow[t]{3}{*}{ ABBL } & SME loan & 30,180 & 31,740 & 37,380 & 42,690 & 47,510 & 1.57 \\
\hline & Total loans & 94,638 & 106,066 & 140,121 & 177,571 & 209,725 & 2.22 \\
\hline & SME loan to total loans (\%) & 31.89 & 29.92 & 26.68 & 24.04 & 22.65 & $-9.24 \%$ \\
\hline \multirow[t]{3}{*}{ EBL } & SME loan & 10,449 & 13,448 & 16,640 & 18,279 & 19,518 & 1.87 \\
\hline & Total loans & 81,774 & 96,720 & 102,910 & 118,291 & 130,226 & 1.59 \\
\hline & SME loan to total loans (\%) & 12.78 & 13.90 & 16.17 & 15.45 & 14.99 & $2.21 \%$ \\
\hline \multirow[t]{3}{*}{$J B L$} & SME loan & 2048.5 & 2962.8 & 4048.8 & 6454.9 & $19,295.9$ & 9.42 \\
\hline & Total loans & $56,611.79$ & $54,887.03$ & $67,669.38$ & $77,899.79$ & $87,252.28$ & 1.54 \\
\hline & SME loan to total loans (\%) & 3.62 & 5.40 & 5.98 & 8.29 & 22.12 & $18.50 \%$ \\
\hline \multirow[t]{3}{*}{ MBL } & SME loan & 3833.56 & 4597.81 & 7250 & 9068.66 & $11,656.87$ & 3.04 \\
\hline & Total loans & $79,999.80$ & $93,610.87$ & $97,688.50$ & $117,060.03$ & $126,338.83$ & 1.58 \\
\hline & SME loan to total loans (\%) & 4.79 & 4.91 & 7.42 & 7.75 & 9.23 & $4.43 \%$ \\
\hline \multirow[t]{3}{*}{ IFICBL } & SME loan & $14,225.2$ & NA & $16,794.6$ & $19,630.2$ & $20,271.8$ & 1.43 \\
\hline & Total loans & 64,641 & 77,160 & 84,110 & 102,282 & 123,269 & 1.91 \\
\hline & SME loan to total loans (\%) & 22.01 & 0.00 & 19.97 & 19.19 & 16.45 & $-5.56 \%$ \\
\hline \multirow[t]{3}{*}{ UBL } & SME loan & N/A & N/A & $35,015.5$ & 35,956 & $26,668.4$ & 0.76 \\
\hline & Total loans & $54,010.3$ & $61,328.6$ & $64,829.8$ & $74,198.9$ & $75,806.9$ & 1.40 \\
\hline & SME loan to total loans (\%) & 0.00 & 0.00 & 54.01 & 48.46 & 35.18 & $-18.83 \%$ \\
\hline \multirow[t]{3}{*}{ SBL } & SME loan & $14,430.0$ & $17,818.60$ & $21,494.05$ & $28,946.70$ & $34,514.18$ & 2.39 \\
\hline & Total loans & $107,288.56$ & $126,968.97$ & $134,863.82$ & $147,070.81$ & $168,878.46$ & 1.57 \\
\hline & SME loan to total loans (\%) & 13.45 & 14.03 & 15.94 & 19.68 & 20.44 & $6.99 \%$ \\
\hline \multirow[t]{3}{*}{ NBL } & SME loan & NA & NA & NA & $28,428.00$ & $32,848.83$ & 1.16 \\
\hline & Total loans & $115,388.89$ & $126,169.79$ & $151,098.98$ & $172,964.72$ & $186,179.45$ & 1.61 \\
\hline & SME loan to total loans (\%) & 0.00 & 0.00 & 0.00 & 16.44 & 17.64 & $1.21 \%$ \\
\hline
\end{tabular}

Source: Compiled and calculated by the researchers from the Annual Reports of selected PCBs, 2011-2015 
Table 3 Agricultural Disbursement of Selected PCBs

\begin{tabular}{|c|c|c|c|c|c|c|c|}
\hline \multirow{2}{*}{$\begin{array}{l}\text { Name } \\
\text { of PCB }\end{array}$} & \multirow[t]{2}{*}{ Particular } & \multicolumn{5}{|c|}{ Year-Wise Data (Amount in Million BDT) } & \multirow{2}{*}{$\begin{array}{l}\text { Growth } \\
\text { Over } \\
\text { the } \\
\text { Period } \\
\text { (Times) }\end{array}$} \\
\hline & & 2011 & 2012 & 2013 & 2014 & 2015 & \\
\hline \multirow[t]{2}{*}{ IBBL } & Loan to agricultural sector & 10,210 & 11,703 & 13,074 & 13,199 & 9716 & 0.95 \\
\hline & Agricultural loan to total loans (\%) & 3.33 & 3.13 & 3.24 & 2.84 & 1.83 & $-1.51 \%$ \\
\hline \multirow[t]{2}{*}{ UCBL } & Loan to agricultural sector & N/A & N/A & N/A & 2762.60 & 2787.20 & 1.01 \\
\hline & Agricultural loan to total loans (\%) & N/A & N/A & N/A & 1.58 & 1.41 & $-0.17 \%$ \\
\hline \multirow[t]{2}{*}{ DBBL } & Loan to agricultural sector & $11,257.00$ & 5486.91 & 1900.74 & 1978.70 & 2402.57 & 0.21 \\
\hline & Agricultural loan to total loans (\%) & 14.13 & 5.98 & 1.78 & 1.59 & 1.58 & $-12.55 \%$ \\
\hline \multirow[t]{2}{*}{ DBL } & Loan to agricultural sector & 1282 & 1620 & 1642 & 1965 & 2044 & 1.59 \\
\hline & Agricultural loan to total loans (\%) & 1.68 & 1.79 & 1.64 & 1.90 & 1.73 & $0.05 \%$ \\
\hline \multirow[t]{2}{*}{ EXBL } & Loan to agricultural sector & 300.00 & 1585.30 & 2428.70 & 2760.20 & 2886.40 & 9.62 \\
\hline & Agricultural loan to total loans (\%) & 0.30 & 1.34 & 1.69 & 1.55 & 1.47 & $1.17 \%$ \\
\hline \multirow[t]{2}{*}{ EBL } & Loan to agricultural sector & NA & 2345 & 829 & NA & 4437 & 1.89 \\
\hline & Agricultural loan to total loans (\%) & 0.00 & 2.42 & 0.81 & 0.00 & 3.41 & $0.98 \%$ \\
\hline \multirow[t]{2}{*}{$J B L$} & Loan to agricultural sector & 513.2 & 1484.0 & 1199.0 & 1073.8 & 1816.4 & 3.54 \\
\hline & Agricultural loan to total loans (\%) & 0.91 & 2.70 & 1.77 & 1.38 & 2.08 & $1.18 \%$ \\
\hline \multirow[t]{2}{*}{ MBL } & Loan to agricultural sector & 679.81 & 1421.18 & 2217.90 & 1785.80 & 2202.19 & 3.24 \\
\hline & Agricultural loan to total loans (\%) & 0.85 & 1.52 & 2.27 & 1.53 & 1.74 & $0.89 \%$ \\
\hline \multirow[t]{2}{*}{ SIBL } & Loan to agricultural sector & 362 & 758 & 745 & 2814 & 3769 & 10.41 \\
\hline & Agricultural loan to total loans (\%) & 0.45 & 0.79 & 0.87 & 3.35 & 3.89 & $3.44 \%$ \\
\hline \multirow[t]{2}{*}{ UBL } & Loan to agricultural sector & NA & 1840.8 & 1186.3 & 1691.22 & 1807.5 & 0.98 \\
\hline & Agricultural loan to total loans (\%) & 0.00 & 3.00 & 1.83 & 2.28 & 2.38 & $-0.62 \%$ \\
\hline \multirow[t]{2}{*}{ IFICBL } & Loan to agricultural sector & 970 & 643.5 & 773.4 & 230.0 & 1632.70 & 1.68 \\
\hline & Agricultural loan to total loans (\%) & 1.50 & 0.83 & 0.92 & 0.22 & 1.32 & $-0.18 \%$ \\
\hline \multirow[t]{2}{*}{ SBL } & Loan to agricultural sector & & 1087.10 & 603.33 & 760.87 & 1644.59 & 1.51 \\
\hline & Agricultural loan to total loans (\%) & 0.00 & 0.86 & 0.45 & 0.52 & 0.97 & $0.97 \%$ \\
\hline \multirow[t]{2}{*}{ NBL } & Loan to agricultural sector & NA & NA & NA & 1811.28 & 1651.85 & 0.91 \\
\hline & Agricultural loan to total loans (\%) & 0.00 & 0.00 & 0.00 & 1.05 & 0.89 & $-0.16 \%$ \\
\hline
\end{tabular}

Source: Compiled and calculated by the researchers from the Annual Reports of selected PCBs, 2011-2015 
Table 4 Growth in Green Investment of Selected PCBs

\begin{tabular}{|c|c|c|c|c|c|c|c|}
\hline \multirow{2}{*}{$\begin{array}{l}\text { Name } \\
\text { of PCB }\end{array}$} & \multirow[t]{2}{*}{ Particular } & \multicolumn{5}{|c|}{ Year-Wise Data (Amount in Million BDT) } & \multirow{2}{*}{$\begin{array}{l}\text { Growth } \\
\text { Over } \\
\text { the } \\
\text { Period } \\
\text { (Times) }\end{array}$} \\
\hline & & 2011 & 2012 & 2013 & 2014 & 2015 & \\
\hline \multirow[t]{2}{*}{ IBBL } & Total green investment & N/A & $27,007.6$ & 44,457 & $54,751.12$ & $78,000.09$ & 2.89 \\
\hline & Green investment to total loans (\%) & N/A & 7.24 & 11.02 & 11.81 & 14.71 & $7.47 \%$ \\
\hline \multirow[t]{2}{*}{ DBL } & Total green investment & N/A & N/A & N/A & N/A & 8533.22 & N/A \\
\hline & Green investment to total loans (\%) & N/A & N/A & N/A & N/A & 7.24 & N/A \\
\hline \multirow[t]{2}{*}{ EXBL } & Total green investment & NA & 25,000 & $14,197.10$ & $18,282.8$ & $24,243.9$ & 0.97 \\
\hline & Green investment to total loans (\%) & NA & 21.14 & 9.86 & 10.27 & 12.34 & $-8.80 \%$ \\
\hline \multirow[t]{2}{*}{ EBL } & Total green investment & & 16,497 & 22,265 & 16,497 & 22,265 & 1.35 \\
\hline & Green investment to total loans (\%) & 0.00 & 17.06 & 21.64 & 13.95 & 17.10 & 0.0004 \\
\hline \multirow[t]{2}{*}{$J B L$} & Total green investment & NA & NA & 3234.87 & NA & 3451.24 & 1.07 \\
\hline & Green investment to total loans (\%) & 0.00 & 0.00 & 4.78 & 0.00 & 3.96 & -0.008 \\
\hline \multirow[t]{2}{*}{ MBL } & Total green investment & N/A & N/A & 172.07 & 100.0 & 12.5 & 0.073 \\
\hline & Green investment to total loans (\%) & N/A & N/A & 0.18 & 0.09 & 0.01 & -0.0017 \\
\hline \multirow[t]{2}{*}{ IFICBL } & Total green investment & N/A & N/A & 1723.83 & 439.28 & N/A & 0.255 \\
\hline & Green investment to total loans (\%) & N/A & N/A & 2.05 & 0.43 & N/A & -0.016 \\
\hline \multirow[t]{2}{*}{ UBL } & Total green investment & 10.32 & 25.64 & 12.39 & 186.70 & 343.22 & 33.26 \\
\hline & Green investment to total loans (\%) & 0.02 & 0.04 & 0.02 & 0.25 & 0.45 & 0.0043 \\
\hline \multirow[t]{2}{*}{ SBL } & Total green investment & N/A & N/A & 4.30 & $13,407.8$ & $17,532.5$ & 4077.33 \\
\hline & Green investment to total loans (\%) & NA & NA & 0.00 & 9.12 & 10.38 & 0.104 \\
\hline \multirow[t]{2}{*}{ NBL } & Total green investment & N/A & N/A & N/A & 938.7 & 698.89 & 0.74 \\
\hline & Green investment to total loans (\%) & NA & NA & NA & 0.54 & 0.38 & -0.167 \\
\hline
\end{tabular}

Source: Compiled and calculated by the researchers from the Annual Reports of selected PCBs, 2011-2015

Table 5 Mobile Banking Performance of Selected PCBs

\begin{tabular}{llllllll}
\hline $\begin{array}{l}\text { Name } \\
\text { of PCB }\end{array}$ & Particular & \multicolumn{3}{l}{ Year-Wise Data (Amount in Million BDT) } & \multicolumn{2}{c}{$\begin{array}{l}\text { Growth } \\
\text { Over } \\
\text { the } \\
\text { Period } \\
\text { (Times) }\end{array}$} \\
\cline { 3 - 8 } & & 2011 & 2012 & 2013 & 2014 & 2015 & \\
\hline BBL & Total no of mobile bank account & N/A & 2.0 & 10.07 & 15.68 & 20.74 & 10.37 \\
& Total no of agent points & N/A & 0.058 & 0.189 & 0.541 & 1.350 & 23.28 \\
DBBL & Total no of mobile bank account & 0.064 & 0.843 & 2.011 & 3.69 & 6.755 & 105.55 \\
& Total no of agent point & 0.0012 & 0.0206 & 0.0626 & 0.1108 & 0.1292 & 107.67 \\
UCBL & Total number of mobile bank account & N/A & N/A & N/A & 1.32 & 1.66 & 2.26 \\
& Total number of agent point & N/A & N/A & N/A & 0.0397 & 0.0412 & 1.04 \\
\hline
\end{tabular}

Source: Compiled and calculated by the researchers from the Annual Reports of selected PCBs, 2011-2015 
Table 6 ATM and Fast Track Information of DBBL

\begin{tabular}{|c|c|c|c|c|c|c|}
\hline \multirow[t]{2}{*}{ Particular } & \multicolumn{5}{|c|}{ Year-Wise Data (in Numbers) } & \multirow{2}{*}{$\begin{array}{l}\text { Growth } \\
\text { Over } \\
\text { the } \\
\text { Period } \\
\text { (Times) }\end{array}$} \\
\hline & 2011 & 2012 & 2013 & 2014 & 2015 & \\
\hline DBBL ATM units & 1940 & 2366 & 2454 & 2705 & 3588 & 1.85 \\
\hline DBBL Fast tracks & 153 & 235 & 263 & 365 & 524 & 3.42 \\
\hline
\end{tabular}

Source: Compiled by the researchers from the Annual Reports of DBBL, 2011-15

Table 7 Growth in Earning Per Share (EPS*) of Selected PCBS

\begin{tabular}{|c|c|c|c|c|c|c|}
\hline \multirow{2}{*}{$\begin{array}{l}\text { Name } \\
\text { of PCB }\end{array}$} & \multicolumn{5}{|c|}{ Year-Wise Data (Amount in Million BDT) } & \multirow{2}{*}{$\begin{array}{l}\text { Growth } \\
\text { Over } \\
\text { the } \\
\text { Period } \\
\text { (Times) }\end{array}$} \\
\hline & 2011 & 2012 & 2013 & 2014 & 2015 & \\
\hline $\mathrm{IBBL}$ & 4.84 & 4.42 & 3.40 & 2.49 & 1.88 & 0.39 \\
\hline UCBL & 2.93 & 1.58 & 3.05 & 3.65 & 3.96 & 1.35 \\
\hline DBBL & 10.8 & 11.6 & 10.0 & 11.0 & 15.1 & 1.40 \\
\hline DBL & 4.64 & 1.5 & 3.56 & 3.57 & 2.3 & 0.50 \\
\hline EXBL & 2.18 & 2.05 & 1.65 & 1.93 & 1.55 & 0.71 \\
\hline $\mathrm{BBL}$ & 4.29 & 1.32 & 2.47 & 3.19 & 3.43 & 0.80 \\
\hline$A B B L$ & 2.22 & 2.40 & 1.69 & 2.10 & 2.12 & 0.95 \\
\hline $\mathrm{EBL}$ & 4.12 & 3.72 & 4.20 & 3.45 & 3.63 & 0.88 \\
\hline $\mathrm{JBL}$ & 3.65 & 2.32 & 2.53 & 2.19 & 2.67 & 0.73 \\
\hline$M B L$ & 3.49 & 2.26 & 2.68 & 1.61 & 1.88 & 0.54 \\
\hline SIBL & 2.10 & 2.59 & 1.78 & 1.02 & 1.76 & 0.84 \\
\hline UBL & 4.99 & 3.40 & 3.28 & 3.47 & 3.76 & 0.75 \\
\hline IFICBL & 2.16 & 2.90 & 3.07 & 3.07 & 1.76 & 0.81 \\
\hline $\mathrm{SBL}$ & 2.19 & 1.89 & 3.68 & 4.18 & 3.35 & 1.53 \\
\hline NBL & 4.29 & 1.05 & 1.36 & 1.55 & 2.24 & 0.52 \\
\hline
\end{tabular}

*EPS against the face value of BDT 10

Source: Compiled and calculated by the researchers from the Annual Reports of selected PCBs, 2011-2015 
Table 8 Contribution of Selected PCBs to National Exchequer

\begin{tabular}{|c|c|c|c|c|c|c|}
\hline \multirow{2}{*}{$\begin{array}{l}\text { Name } \\
\text { of PCB }\end{array}$} & \multicolumn{5}{|c|}{ Year-Wise Data (Amount in Million BDT) } & \multirow{2}{*}{$\begin{array}{l}\text { Growth } \\
\text { Over } \\
\text { the } \\
\text { Period } \\
\text { (Times) }\end{array}$} \\
\hline & 2011 & 2012 & 2013 & 2014 & 2015 & \\
\hline IBBL & 5476.00 & 8106.11 & $10,963.07$ & $11,465.00$ & $17,392.00$ & 3.18 \\
\hline UCBL & 2227 & 2153 & 2822 & 3167 & 3275 & 1.47 \\
\hline DBBL & 2280 & 2497 & 2179 & 2698 & 3223 & 1.41 \\
\hline DBL & 1489 & 738 & 849.77 & 1191.84 & 938.40 & 0.63 \\
\hline EXBL & 1465.69 & 1530.82 & 1333.94 & 1925.99 & 1565.24 & 1.07 \\
\hline BBL & 2683.27 & 3319.19 & 3065.85 & 3376.71 & 3218.03 & 1.20 \\
\hline ABBL & 1629 & 1752 & 1974 & 2719 & 1489 & 0.91 \\
\hline EBL & 2512 & 3856 & 4716 & 1911.62 & 3879.02 & 1.54 \\
\hline$J B L$ & 1139.82 & 1038.47 & 1149.7 & 500.26 & 1843 & 1.62 \\
\hline MBL & 1270 & 1000 & 1250 & 1100 & 1250 & 0.98 \\
\hline SIBL & 1219 & 1805 & 1078 & 29 & 468 & 0.38 \\
\hline UBL & 1350 & 1300 & 1370 & 1513 & 1018 & 0.75 \\
\hline IFICBL & 1113 & 285 & 1362 & 1132 & 728 & 0.65 \\
\hline SBL & 1802.80 & 2069.85 & 2573.77 & 2519.31 & 1644.59 & 0.91 \\
\hline NBL & 3329.96 & 1820.11 & 1372.75 & 2477.099 & 2489.222 & 0.75 \\
\hline
\end{tabular}

Source: Compiled and calculated by the researchers from the Annual Reports of selected PCBs, 2011-2015

Table 9 Definition of SMEs

\begin{tabular}{llll}
\hline Business Segment & Sector & $\begin{array}{l}\text { Business Size (BDT) } \\
\text { Fixed Asset other than } \\
\text { Land \& Building }\end{array}$ & $\begin{array}{l}\text { Employed } \\
\text { Manpower } \\
\text { (Not above) }\end{array}$ \\
\hline Cottage Enterprise & $\begin{array}{l}\text { Manufacturing (Predominant Family } \\
\text { Labor) }\end{array}$ & $\begin{array}{l}\text { Up to 500,00 } \\
\text { Micro Enterprise }\end{array}$ & 10 \\
& Manufacturing & $500,000-5,000,000$ & $10-24$ \\
& Service & Less than 500, 000 & 10 \\
Small Enterprise & Mrade & Less than 500, 000 & 5 \\
& Service & $5,000,000-100,000,000$ & $25-99$ \\
& Trade & $500,000-10,000,000$ & $10-49$ \\
Medium & Manufacturing & $500,000-10,000,000$ & $6-10$ \\
Enterprise & Service & $100,000,000-$ & $100-250$ \\
& Trade & $300,000,000$ & \\
$10,000,000-150,000,000$ & $50-100$ \\
& $10,000,000-150,000,000$ & $11-50$ \\
\hline
\end{tabular}

Source: Bangladesh Bank SMESPD Circular No. 01, dated 19 June 2011, Quoted in Annual Report of Dhaka Bank Limited (2015), p. 84 


\section{Abbreviations}

ABBL: Arab Bangladesh Bank Limited; ATM: Automated Teller Machine; BBL: BRAC Bank Limited; BSEC: Bangladesh Securities and Exchange Commission; CDBL: Central Depository Bangladesh Limited; CDM: Cash Deposit Machine; CSE: Chittagong Stock Exchange; CSR: Corporate Social Responsibility; CSV: Creating Shared Value; DBBL: Dutch-Bangla Bank Limited; DBL: Dhaka Bank Limited; DSE: Dhaka Stock Exchange; EBL: Eastern Bank Limited; EXBL: EXIM Bank Limited; IBBL: Islami Bank Bangladesh Limited; IFICBL: IFIC Bank Limited; JBL: Jamuna Bank Limited; MBL: Mercantile Bank Limited; MFI: Micro Finance Institute; NBL: National Bank Limited; NGO: Non-Government Organization; NPL: Non-performing loan; PCB: Private Commercial Bank; SBL: Southeast Bank Limited; SIBL: Shahjalal Islami Bank Limited; SME: Small and Medium Scale Enterprise; SMS : Short Message Service; UBL: Uttara Bank Limited; UCBL: United Commercial Bank Limited

\section{Acknowledgements}

$\mathrm{N} / \mathrm{A}$

\section{Funding}

N/A

\section{Availability of data and materials}

The study is based on secondary data which have been collected from the annual audited reports of sampled banks. All data generated and analyzed during the study are included in this article. All sample banks that were analyzed for this study maintain company websites and provide information regarding products and services via downloadable PDF format documents of their annual reports.

\section{Authors' contributions}

First author conducted the literature review, data collection, tabulation, and empirical studies. Second author assisted to check and interpret the whole paper several times including referencing. Both authors read and approved the final manuscript.

\section{Competing interests}

The authors declare that they have no competing interest.

\section{Publisher's Note}

Springer Nature remains neutral with regard to jurisdictional claims in published maps and institutional affiliations.

\section{Author details}

'Department of Humanities, Rajshahi University of Engineering \& Technology (RUET), Rajshahi 6204, Bangladesh.

${ }^{2}$ Department of Accounting and Information Systems, University of Rajshahi, Rajshahi 6205, Bangladesh.

Received: 15 October 2018 Accepted: 10 January 2019

Published online: 18 January 2019

\section{References}

Ahmad NNN, Sulaiman M, Siswantoro D (2003) Corporate social responsibility disclosure in Malaysia: an analysis of annual reports of KLSE listed companies. International Journal of Economics, Management and Accounting 11(1):1-37

Bendell J (2004) Barricades and boardrooms: a contemporary history of the corporate accountability movement. UNRISD Technology, Business and Society Programme Paper 13:1-63

Bissoon O (2018) Corporate social responsibility in Mauritius: an analysis of annual reports of multinational hotel groups. Asian Journal of Sustainability and Social Responsibility 3(2):1-19. https://doi.org/10.1186/s41180-017-0017-4

Bowen HR (1953) Social responsibilities of the businessman. Harper \& Row, New York

Broomhill R (2007) Corporate social responsibility: key issues and debates. Dunstan Paper-Don Dunstan Foundation 1:1-20

Burke L, Logsdon JM (1996) How corporate social responsibility pays off? Long Range Plan 29(4):495-502. https://doi.org/10. 1016/0024-6301(96)00041-6

Campbell JL (2007) Why would corporations behave in socially responsible ways? An institutional theory of corporate social responsibility. Acad Manag Rev 32(3):946-967. https://doi.org/10.5465/amr.2007.25275684

Carroll AB (1979) A three-dimensional conceptual model of corporate social performance. Acad Manag Rev 4:497-505. https://doi.org/10.5465/amr.1979.4498296

Carroll AB (1991) The pyramid of corporate social responsibility: toward the moral management organizational stakeholders, Business Horizons 34:39-48

Carroll AB (1999) Corporate social responsibility: evolution of a definitional construct. Bus Soc 38(3):268-295. https://doi.org/ $10.1177 / 000765039903800303$

Clarkson ME (1995) A stakeholder framework for analyzing and evaluating corporate social performance. Acad Manag Rev 20(1):92-117. https://doi.org/10.5465/amr.1995.9503271994

Cochran PL, Wood RA (1984) Corporate social responsibility and financial performance. Acad Manag J 27(1):42-56 http:// www.jstor.org/stable/255956

Davis K (1960) Can business affords to ignore social responsibilities? Calif Manag Rev 2(3):70-76. https://doi.org/10.2307/ 41166246

Davis K, Blomstrom RL (1966) Business and its environment. McGraw-Hill, New York

De Villiers C, Van Staden CJ (2006) Can less environmental disclosure have a legitimizing effect? Evidence from Africa. Acc Organ Soc 31(8):763-781

Deegan C, Gordon B (1996) A study of the environmental disclosure practices of Australian corporations. Account Bus Res 26(3):187-199 
Dembek K, Singh P, Bhakoo V (2016) Literature review of shared value: a theoretical concept or a management buzzword? J Bus Ethics 137(2):231-267. https://doi.org/10.1007/s10551-015-2554-z

Epstein EM (1989) Business ethics, corporate good citizenship and the corporate social policy process: a view from the United States. J Bus Ethics 8(8):583-595. https://doi.org/10.1007/bf00383027

Fitch HG (1976) Achieving corporate social responsibility. Acad Manag Rev 1:38-46

Freeman RE (1984) Strategic management: a stakeholder approach. Pitman, Boston

Gray R, Kouhy R, Lavers S (1995) Corporate social and environmental reporting: a review of the literature and a longitudinal study of UK disclosure. Account Audit Account J 8(2):47-77

Griffin JJ, Mahon JF (1997) The corporate social performance and corporate financial performance debate: twenty-five years of incomparable research. Bus Soc 36(1):5-31. https://doi.org/10.1177/000765039703600102

Hart SL, Milstein MB (2003) Creating sustainable value. Acad Manag Exec 17(2):56-67. https:/doi.org/10.5465/ame.2003.10025194

Hemingway CA (2002) An exploratory analysis of corporate social responsibility: definitions, motives and values. Research memorandum (34), Hull University business school, Hull, HU6 7RX, UK

Islam MR (2017) Banking on shared value: a study on private commercial banks in Bangladesh. University of Rajshahi, Dissertation

Islam MR, Hossain SZ (2018a) SME customers' perceptions on banking on shared value in Bangladesh. International Journal of Economics, Management and Accounting 26(1):109-133 http://journals.iium.edu.my/enmjournal/index.php/enmj/article/ view/568/278. Accessed 8 Oct 2018

Islam MR, Hossain SZ (2018b) Creating shared value through mobile financial services in Bangladesh. Int J Dev Sustain 7(2): 620-638 https://isdsnet.com/ijds-v7n2-14.pdf. Accessed 5 Oct 2018

Jenkins R (2005) Globalization, corporate social responsibility and poverty. Int Aff 81(3):525-540. https://doi.org/10.1111/j. 1468-2346.2005.00467.x

Lapina I, Borkus I, Starineca O (2012) Corporate social responsibility and creating shared value: case of Latvia. World Academy of Science, Engineering and Technology 6:1605-1611 http://waset.org/publications/7540/corporate-social-responsibilityand-creating-shared-value-case-of-latvia. Accessed 16 Apr 2015

Maltz E, Thompson F, Ringold DJ (2011) Assessing and maximizing corporate social initiatives: a strategic view of corporate social responsibility. Journal of Public Affairs 11(4):344-352. https://doi.org/10.1002/pa.384

Margolis JD, Walsh JP (2001) People and profits? The search for a link between a firm's social performance and financial performance. Lawrence Erlbaum Publishers, Mahwah

Matten D, Moon J (2008) Implicit' and 'explicit' CSR: a conceptual framework for a comparative understanding corporate social responsibility. Acad Manag Rev 33(2):404-424 http://carleton.ca/ces/wp-content/uploads/MattenMoon-in-AMR2008.pdf. Accessed 16 Apr 2015

McGuire JW (1963) Business and society. McGraw-Hill, New York

Mcwilliams A, Siegel DS (2000) Corporate social responsibility and financial performance: correlation or misspecification? Strateg Manag J 21(5):603-609. https://doi.org/10.1002/(sici)1097-0266(200005)21:53.3.co;2-v

Mcwilliams A, Siegel DS, Wright PM (2006) Corporate social responsibility: strategic implications. J Manag Stud 43(1):1-18. https://doi.org/10.1111/j.1467-6486.2006.00580.x

Neu D, Warsame H, Pedwell K (1998) Managing public impressions: environmental disclosures in annual reports. Acc Organ Soc 23(3):265-282

Neuman WL, Kreuger L (2003) Social work research methods: qualitative and quantitative approaches. Allyn and Bacon

Orlitzky M, Schmidt FL, Rynes SL (2003) Corporate social and financial performance: a meta-analysis. Organization Studies 24(3): 403-441 https:/staging.community-wealth.org/sites/clone.community-wealth.org/files/downloads/article-orlitzky-et-al.pdf. Accessed 16 Jan 2019

Pfitzer M, Bockstette V, Stamp M (2013) Innovating for shared value: companies that deliver both social benefit and business value rely on five mutually reinforcing elements. Harvard Business Review, pp 1-10 http://www.philoma.org/docs/2013 2014_Valeur_actionnariale_a_partagee/Pfitzer_and_co__HBR_-Innovating_for_shared_val ue.pdf. Accessed 11 Jan 2015

Porter ME, Hills G, Pfitzer M, Patscheke S, Hawkins E (2012) Measuring shared value: how to unlock value by linking social and business results, pp 1-24 http://www.fsg.org/tabid/191/Articled/740/Default.aspx?srpush=true. Accessed 15 Feb 2018

Porter ME, Kramer MR (2006) Strategy and society: The link between competitive advantage and corporate social responsibility. Harvard Business Review 84(12):1-15 https://www.sharedvalue.org/sites/default/files/resource-files/ Strategy_and_Society.pdf. Accessed 11 Jan 2015

Porter ME, Kramer MR (2011) The big idea: creating shared value; how to reinvent capitalism—and unleash a wave of innovation and growth. Harvard Business Review, pp 1-17 http://www.nuovavista.com/ SharedValuePorterHarvardBusinessReview.PDF. Accessed 11 Jan 2015

Rizk R, Dixon R, Woodhead A (2008) Corporate social and environmental reporting: a survey of disclosure practices in Egypt. Social Responsibility Journal 4(3):306-323

Smith RE (2011) Defining corporate social responsibility: a systems approach for socially responsible capitalism. Thesis, University of Pennsylvania. http://repository.upenn.edu/cgi/viewcontent.cgi?article=1009\&context=od_theses_mp. Accessed 29 Aug 2016)

Spitzeck H, Boechat C, Leão SF (2013) Sustainability as a driver for innovation-towards a model of corporate social entrepreneurship at Odebrecht in Brazil. Corporate Governance: The International Journal of Business in Society 13(5): 613-625. https://doi.org/10.1108/cg-06-2013-0080

Vogel D (1992) The globalization of business ethics: why America remains distinctive. Calif Manag Rev 35(1):30-39. https:// doi.org/10.2307/41166711

Waddock S (2008) Building a new institutional infrastructure for corporate responsibility. Acad Manag Perspect 22(3):87-108. https://doi.org/10.5465/amp.2008.34587997

Wood DJ (1991) Corporate social performance revisited. Acad Manag Rev 16(4):691-718. https://doi.org/10.5465/amr.1991. 4279616

World Business Council for Sustainable Development (1998) Corporate social responsibility: meeting changing expectations. http://www.wbcsd.org/pages/edocument/edocumentdetails.aspx?id=82\&nosearchcontextkey=true. Accessed 6 Sept 2016 